\title{
OPEN Prediction model for sap flow in cacao trees under different radiation intensities in the western Colombian Amazon
}

\author{
Juan Carlos Suárez ${ }^{1,2,3 凶}$, Fernando Casanoves ${ }^{4}$, Marie Ange Ngo Bieng ${ }^{4,5}$, \\ Luz Marina Melgarejo ${ }^{6}$, Julio A. Di Rienzo ${ }^{7}$ Cristina Armas ${ }^{8}{ }^{8}$
}

In this study, we measured diurnal patterns of sap flow $\left(V_{s}\right)$ in cacao trees growing in three types of agroforestry systems (AFs) that differ in the incident solar radiation they receive. We modeled the relationship of $V_{s}$ with several microclimatic characteristics of the AFs using mixed linear models. We characterized microclimatic variables that may have an effect on diurnal patterns of sap flow: air relative humidity, air temperature, photosynthetically active radiation and vapor pressure deficit. Overall, our model predicted the differences between cacao $V_{s}$ in the three different AFs, with cacao plants with dense Musaceae plantation and high mean diurnal incident radiation $\left(H_{P A R}\right)$ displaying the highest differences compared to the other agroforestry arrangements. The model was also able to predict situations such as nocturnal transpiration in $H_{P A R}$ and inverse nocturnal sap flows indicative of hydraulic redistribution in the other AFs receiving less incident radiation. Overall, the model we present here can be a useful and cost-effective tool for predicting transpiration and water use in cacao trees, as well as for managing cacao agroforestry systems in the Amazon rainforest.

Cacao cultivation is one of the most important agricultural activities in the world; in 2019, 4.8 million tons of beans were produced across 9.9 million hectares ${ }^{1,2}$. Up to 50 million people depend on these cultivations ${ }^{1}$. Cacao is typically grown in tropical climates, mostly under high insolation regimes that impact the cultivation of $\mathrm{cacao}^{3-5}$. As it is a tree crop particularly sensitive to drought ${ }^{6,7}$, shading improves the microclimatic conditions where cacao trees grow, consequently improving the plants' water status ${ }^{8}$ that has an overall positive impact on crop production ${ }^{9,10}$. For these reasons, $70 \%$ of the area covered by cacao plantations throughout Latin America is managed through agroforestry arrangements where cacao crops are planted under the shade of other trees, or of annual and evergreen crops ${ }^{11}$.

Modelling transpiration fluxes of target tree crops is key to analyzing the water balance of any agroforestry system (AF). Transpiration is generally analyzed using the Penman-Monteith adjusted equation that is based on, among other inputs, field measurements of sap flow ${ }^{12-14}$. In such models, transpiration is calculated using direct measures of the diurnal accumulated sap flow density, a modeling approach that has been applied for many major crops including cacao ${ }^{15-18}$, coffee ${ }^{19-22}$, apple $\mathrm{e}^{23,24}$, papaya ${ }^{25,26}$, in vineyards ${ }^{27,28}$ and in other tropical tree crop species ${ }^{29}$.

Diurnal sap flow measurements are costly, both in terms of equipment and data post-processing ${ }^{30,31}$. Thus, some efforts have been made to model diurnal sap flow, such as the Jarvis-type model ${ }^{32}$, which predicts sap flow by using non-linear models that depend on a single environmental factor (e.g., photosynthetically active radiation or vapor pressure deficit ${ }^{16,18}$ ) or a group of environmental variables ${ }^{33}$. All such models consider that vapor

\footnotetext{
${ }^{1}$ Facultad de Ingeniería, Programa de Ingeniería Agroecológica, Universidad de la Amazonia, Florencia-Caquetá, Colombia. ${ }^{2}$ Facultad de Ciencias Agropecuarias, Maestría Sistemas Sostenibles de Producción, Universidad de la Amazonia, Florencia-Caquetá, Colombia. ${ }^{3}$ Centro de Investigaciónes Amazónicas CIMAZ Macagual, Grupo de Investigaciones Agroecosistemas y Conservación en Bosques Amazónicos-GAIA, Florencia, Caqueta', Colombia. ${ }^{4}$ CATIE - Centro Agronómico Tropical de Investigación y Enseñanza, Turrialba 30501, Costa Rica. ${ }^{5}$ CIRAD, UR Forêts et Sociétés, 34398 Montpellier Cedex 5, France. ${ }^{6}$ Departamento de Biología, Laboratorio de Fisiología y Bioquímica Vegetal, Universidad Nacional de Colombia - Sede Bogotá, Bogotá, Colombia. ${ }^{7}$ Facultad de Ciencias Agropecuarias, Universidad Nacional de Córdoba, Córdoba, Argentina. ${ }^{8}$ Estación Experimental de Zonas Áridas, Spanish National Research Council (CSIC), Carretera de Sacramento s/n, E-04120 La Cañada de San Urbano, Almería, Spain. ${ }^{\boxplus e m a i l: ~ j u . s u a r e z @ u d l a . e d u . c o ~}$
} 


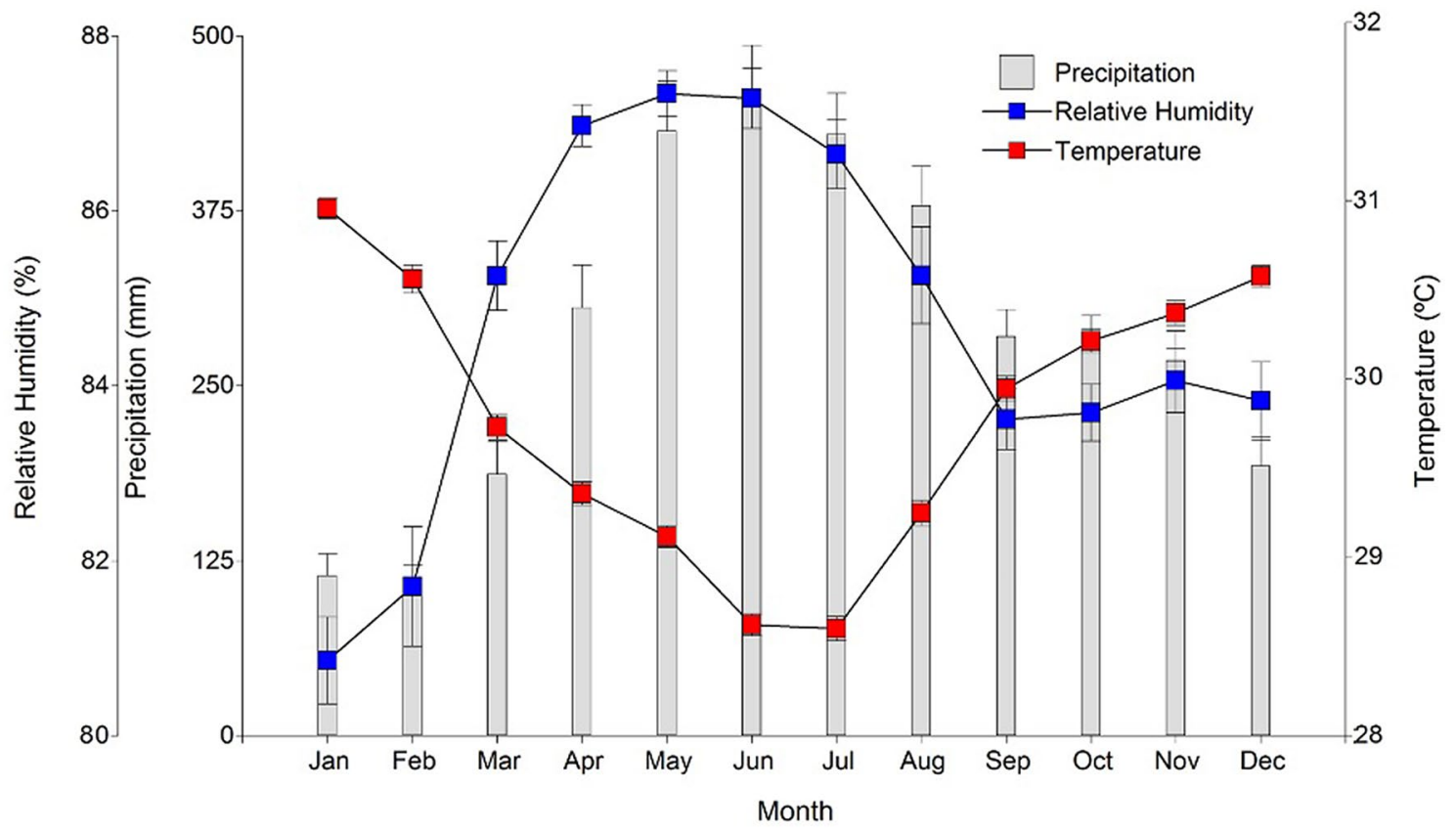

Figure 1. Climate diagram of the Continental Amazon region, including monthly precipitation, mean monthly temperature, and air relative humidity (values calculated based on the last 30 years of climatic data). The driest month is January (high air temperature, low precipitation, and low air relative humidity).

pressure deficit $(V P D)$ and photosynthetically active radiation $(P A R)$ are the microclimatic variables that have the largest impact on sap flow; however, this assumption may be an over-simplification ${ }^{16,17,34}$. In a cacao AF, the shade of companion species impacts many other microclimatic variables such as incident radiation, diurnal amplitude and mean temperature, and relative air humidity. These microclimatic variables may also impact the diurnal production and transpiration of the crop, having effects on the crop that could be independent of the ones caused by VPD or PAR alone. In such cases, accurate sap flow predictions require more complex models that take into account the simultaneous effects of these key microclimatic variables, which are affected by the modification of the AF structure. Once these models are developed, they can be used to determine diurnal patterns of tree sap flow in each type of AF; posterior calculations of sap flow would then only require the measurement of these microclimatic variables. These models would ultimately be more affordable and practical tools to calculate transpiration and water use of single cacao trees ${ }^{15-18,33}$ as well as of the entire cacao plantation grown in different AFs. Blooming in cacao trees occurs during the relative dry season, and flower and fruit set productions would depend on plant water status and $\mathrm{C}$ assimilation rates ${ }^{35}$. Diurnal sap flow rates are a proxy of diurnal tree transpiration rates, gas exchange and $\mathrm{C}$ fixation ${ }^{36,37}$ that, during the onset of the reproductive period, can be assigned to flower and fruit production. Thus, those AFs displaying adequate cacao sap flow dynamics during cacao reproductive period would increase the production of flowers ${ }^{38}$ and fruit set ${ }^{39}$.

The overall aim of the study is to propose a cost-effective model to predict sap flow in cacao trees based on multiple microclimatic variables relevant to cacao AFs in the continental Amazon region during the relative dry period when cacao trees flower and fructificate. The climate and overall environmental conditions of cacao plantations are similar in this region, and all plantations use similar companion species to arrange the agroforestry structure. More specifically, in this study we measured diurnal cacao sap flow $\left(V_{s}\right)$ and modelled it based on different microclimatic variables (air relative humidity, air temperature, photosynthetically active radiation, and $V P D)$. We then analyzed the diurnal patterns of sap flow movement and day-night directions of $V_{s}$ in three cacao AFs in the Continental Amazon region. These AFs differed in the density and type of companion species, generating different diurnal incident radiation intensities among AFs. After the validation of the $V s$ model, we discussed the interest of this modeling approach, specifically in relation to its usefulness for calculating diurnal water use of cacao plantations under different AF managements, as well as its potential effects on cacao production.

\section{Materials and methods}

Study site and AF characteristics. Sap flow measurements were taken from cacao trees in three agroforestry systems at the Centro de Investigaciones Amazónicas (Amazonian Investigations Center) CIMAZ Macagual-Universidad de la Amazonia (137' $\mathrm{N}$ and 7536' $\mathrm{W}$ at $360 \mathrm{~m}$ a.s.l.), Colombia. The three AFs differed in structure (number and type of companion species) and incident radiation (see below). The climate is warmhumid, characteristic of Amazonian tropical rainforest ecosystems, with a mean annual precipitation of 3443 $\mathrm{mm}, 1200$ sunshine hours per year, a temperature between 28.5 and $31^{\circ} \mathrm{C}$ and a relative humidity between 81 and $88 \%$ (Fig. 1). Sap flow was measured over the course of two weeks during the period of minimum rainfall in the region (November to February). We selected this period for measurements because cacao plant production, transpiration, flowering and fruit-set differed the most across AFs during this relatively dry season, and 


$$
H_{P A R}
$$

$a$
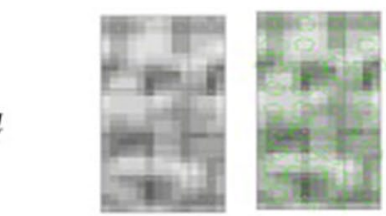

$b$
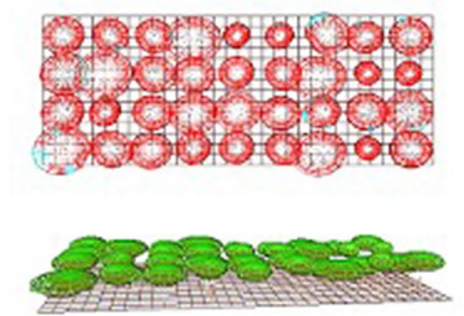

$c$

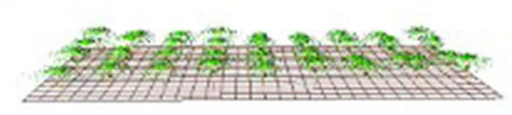

$M_{P A R}$
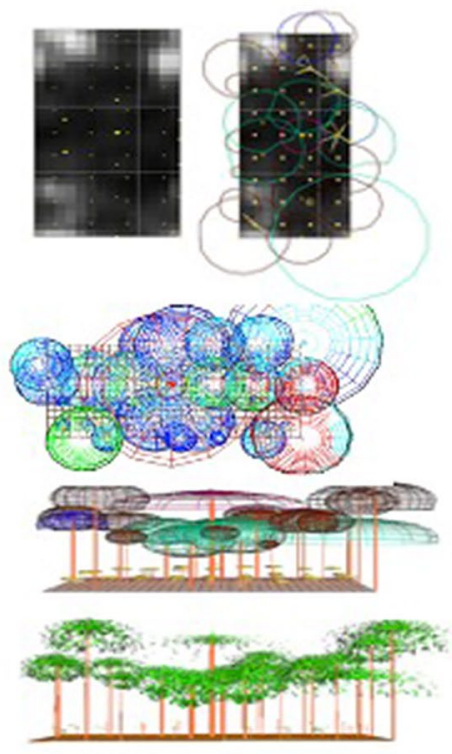

$L_{P A R}$

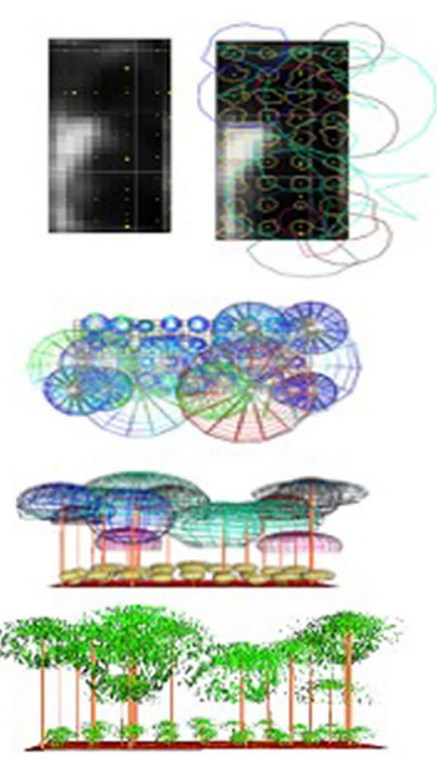

Figure 2. Digital models of the horizontal and vertical structure of each type of agroforestry system (AF) studied. The grayscale in (a) corresponds to the level of shadow generated by the shade canopy (darker corresponds to less incident radiation); upper or horizontal (b) and lateral or vertical (c) profiles of the agroforestry systems with each of the companion species defined with different colors. Digital models were built with SExI-FS ${ }^{40}$ and Shademotion ${ }^{41}$ software's. The agroforestry arrangements are: cacao AF with dense Musaceae plantation and high mean diurnal incident radiation $\left(\mathrm{H}_{\mathrm{PAR}}\right)$; cacao AF with low density of clustered vegetation and medium mean diurnal incident radiation $\left(\mathrm{M}_{\mathrm{PAR}}\right)$; and cacao $\mathrm{AF}$ with high density diversified multistrata vegetation and low mean diurnal incident radiation $\left(\mathrm{L}_{\mathrm{PAR}}\right)$. Other characteristics of the AFs are described in methods and Table 1.

adequate cacao response to potential drought spells is of great economic importance. Anyhow, as major abiotic characteristics (climate, soil and topography) were equal in all AFs, and the period studied was a relatively mild dry period, we did not expect major differences in soil water contents across AFs, and expect that major differences in cacao physiological responses across AFs would be caused by the different microclimatic conditions and incident radiation among AFs. During the rest of the year, the climate is particularly humid and cloudy, and a preliminary analysis of cacao tree physiological responses across AFs did not render significant results.

The three AF plots analyzed in this study were $25 \times 50 \mathrm{~m}$ in size. The cacao plants were all clones (and thus of the same age), planted in the AFs in October 2012 in a regular pattern with a distance of $3 \mathrm{~m}$ between plants, irrespective of the AF. Although the cacao plantation was identical in the three plots, each AF differentiated itself based on the type and density of the companion species (henceforth called vegetation), which were planted in 2008 in rows with a north-south orientation and created an upper canopy with varying levels of shade. Two of the AFs included companion timber species (Cariniana pyriformis, Calycophyllum spruceanum), and a third AF included Musaceae species (plantain; Musa paradisiaca). The three cacao AFs compared in this study were (Fig. 2; Table 1):

i. Cacao AFs with dense Musaceae plantation and high mean diurnal incident radiation $\left(H_{P A R}\right)$ with temporary shade generated by plantain plants, planted at a density of 527 plants ha ${ }^{-1}$ (i.e., one plantain plant per $6 \times 3$ $\mathrm{m}$ area). The diurnal mean PAR transmitted to cacao was $700 \mu \mathrm{mol} \mathrm{m}^{-2} \mathrm{~s}^{-1}$ (with mean midday values of $\left.1300 \mu \mathrm{mol} \mathrm{m}{ }^{-2} \mathrm{~s}^{-1}\right)$;

ii. Cacao AFs with a low density of clustered vegetation and medium mean diurnal incident radiation $\left(M_{P A R}\right)$ with average shade that is generated by trees with thin crowns (Cariniana pyriformis, Calycophyllum spruceanum), planted at a density of 35 trees ha $^{-1}$ (i.e., one tree per $12 \times 25 \mathrm{~m}$ area). The diurnal mean PAR transmitted to cacao was $400 \mu \mathrm{mol} \mathrm{m} \mathrm{m}^{-2} \mathrm{~s}^{-1}$ (with mean midday values of $900 \mu \mathrm{mol} \mathrm{m} \mathrm{m}^{-2} \mathrm{~s}^{-1}$ );

iii. Cacao AFs with high density multistrata vegetation and low mean diurnal incident radiation $\left(L_{P A R}\right)$ with intense shade, generated by the same trees as $\mathrm{M}_{\mathrm{PAR}}$ (Cariniana pyriformis, Calycophyllum spruceanum) but planted at a density of 55 trees $\mathrm{ha}^{-1}$ (i.e., one tree per $12 \times 15 \mathrm{~m}$ area). There is a diurnal mean PAR transmitted to cacao was $300 \mu \mathrm{mol} \mathrm{m}^{-2} \mathrm{~s}^{-1}$ (with mean midday values of $500 \mu \mathrm{mol} \mathrm{m} \mathrm{m}^{-2} \mathrm{~s}^{-1}$ ).

Monitoring sap flow in the sampled cacao trees. Sap flow was quantified using the SFM1 sap flow meter (ICT International Pty Ltd., Armidale, Australia) installed in the main trunk of four randomly chosen cacao plants in each AF at a height of $20 \mathrm{~cm}$ from the ground. Because the plants are clones of the same age, we assumed that differences recorded at the physiological level between systems are due to the effect of the AFs 


\begin{tabular}{|c|c|c|c|}
\hline & \multicolumn{3}{|c|}{ Agroforestry system } \\
\hline & $\mathbf{H}_{\mathrm{PAR}}$ & $\mathbf{M}_{\mathrm{PAR}}$ & $\mathbf{L}_{\mathrm{PAR}}$ \\
\hline \multicolumn{4}{|l|}{ Cacao trees } \\
\hline \multicolumn{4}{|l|}{ Theobroma cacao } \\
\hline Main stem diameter $(\mathrm{cm})$ & $7.32 \pm 0.52$ & $7.22 \pm 0.45$ & $7.14 \pm 0.36$ \\
\hline Height $(\mathrm{m})$ & $2.29 \pm 0.03$ & $2.15 \pm 0.02$ & $1.96 \pm 0.02$ \\
\hline Crown diameter $\left(\mathrm{m}^{2}\right)$ & $7.42 \pm 0.37$ & $7.19 \pm 0.52$ & $7.11 \pm 0.17$ \\
\hline \multicolumn{4}{|c|}{ Shade canopy accompanying species } \\
\hline \multicolumn{4}{|c|}{ Cariniana pyriformis } \\
\hline $\mathrm{DBH}$ & - & $0.31 \pm 0.02$ & $0.35 \pm 0.04$ \\
\hline Height $(\mathrm{m})$ & - & $9.75 \pm 0.25$ & $10.5 \pm 0.82$ \\
\hline Crown diameter $\left(\mathrm{m}^{2}\right)$ & - & $8.1 \pm 0.4$ & $13.3 \pm 1.2$ \\
\hline \multicolumn{4}{|l|}{ Calycophyllum spruceanum } \\
\hline DBH & - & $0.15 \pm 0.01$ & $0.18 \pm 0.04$ \\
\hline Height $(\mathrm{m})$ & - & $11.5 \pm 0.67$ & $11.38 \pm 0.75$ \\
\hline Crown diameter $\left(\mathrm{m}^{2}\right)$ & - & $5.6 \pm 0.57$ & $6.6 \pm 0.58$ \\
\hline
\end{tabular}

Table 1. Different measurements done in cacao trees (Theobroma cacao) and accompanying species in each of the agroforestry systems (AFs) analyzed in this study. These AFs mainly differ in the density and species shading the cacao crop and thus in the incident radiation the cacao crop receive and the associated microclimatic changes. Tree measurements are, main stem diameter (cacao; measured at $20 \mathrm{~cm}$ above ground) or diameter at breast height (DBH, rest of the trees), tree height, and crown diameter. Main characteristics of AFs and their legend are described in the methods section and Fig. 2.

on the microclimatic variables under the canopy, as well as to the effects of these variables on the physiological behavior of cacao, absent confounding factors. Continuous sap flow measurements were made during the end of the dry season, between January 13 and 27 of 2015. These sensors use the Heat Ratio Method (HRM), which was developed and presented by Burgess et al. ${ }^{42}$. Each sensor consists of two thermocouples spaced $15 \mathrm{~mm}$ apart and inserted in the main stem at $5 \mathrm{~mm}$ and $20 \mathrm{~mm}$ depth behind the cambium. In order to calibrate using a reference value of the sap flow velocity (zero), we used the procedure suggested by Burgess et al. ${ }^{42}$ which consists of cutting the stem below the measuring needles and recorded sap velocity $\left(V_{\mathrm{h}}\right)$ afterwards. All corrections for wounds and misalignment of the probes were made according to Burgess et al. ${ }^{42}$. The velocity of the heat pulse $\left(V_{\mathrm{h}}\right)$ can be calculated as a function of different parameters as:

$$
V_{h}=\frac{k}{x} \ln \left(T_{1} / T_{2}\right) 3600
$$

where: $V_{\mathrm{h}}$ is the heat pulse velocity $\left(\mathrm{m} \mathrm{s}^{-1}\right), k$ is thermal diffusivity of green (fresh) wood (with a default value of $\left.0.0025 \mathrm{~cm}^{2} \mathrm{~s}^{-143}\right), x$ is the distance between the heater and each of the thermocouples needles $(\mathrm{cm} ; 0.6 \mathrm{~cm}$ for this particular sensors), and $T_{1}$ and $T_{2}$ are the temperatures $\left({ }^{\circ} \mathrm{C}\right)$ in the position of the needles, located at equidistant points downstream and upstream from the heater. Heat pulse velocity $\left(V_{\mathrm{h}}\right)$ was converted into sap flux density $\left(V_{\mathrm{s}}\right.$ sap flow rate $\left.\mathrm{L} \mathrm{h}^{-1}\right)$ using the equation proposed by Burgess et al. ${ }^{42}$, as:

$$
V_{s}=\frac{b}{s}\left(m_{c}+\frac{C_{w}}{C_{s}}\right) * V_{h} * \mathrm{~S}
$$

where $_{b}$ is the basic density of the dry sapwood (i.e. dry sapwood weight divided by its green volume), ${ }_{s}$ is the sap density (assumed to be the density of water), $m_{c}$ is the water content of the fresh sapwood, $C_{w}$ is the specific heat capacity of the dry wood matrix $\left(1200 \mathrm{~J} \mathrm{~kg}^{-1} \mathrm{~K}^{-1}\right.$ at $\left.20^{\circ} \mathrm{C}^{44}\right), C_{s}$ is the specific heat capacity of the sap (assumed to be that of water, $4186 \mathrm{~J} \mathrm{~kg}^{-1} \mathrm{~K}^{-1}$ at $20^{\circ} \mathrm{C}^{44}$ ), and $\mathrm{S}$ is the cross-sectional area of the conducting sapwood.

Raw heat pulse velocity data collected by the SFM1 Sap Flow Meters were imported into the Sap Flow Tool software (ICT International, Armidale, NSW, Australia) that calculated sap flow, diurnal sap flow and cumulative sap flow rates $\left(\mathrm{L} \mathrm{h}^{-1}\right)$ using the above mentioned functions.

Monitoring microclimatic variables in the AFs under study. A WatchDog 2900ET weather station (Spectrum Technologies, Inc., USA) was placed under the canopy at a height of three meters, and moved within the plot every day to monitor the microclimatic parameters: air relative humidity $\left(R H_{a}\right)$, air temperature $\left(T_{a}\right)$, and photosynthetically active radiation $(P A R)$ at a frequency of once per minute. The vapor pressure deficit $(V P D)$ was calculated based on air temperature and air relative humidity, which were recorded minute by minute using the methodology proposed by Allen et al. ${ }^{45}$ which records the maximum and minimum temperature and humidity values during a given period.

Modelling sap flow under different radiation intensities. The model. We first compared the microclimatic variables across AFs using linear mixed models (LMM) where $R H_{a}, T_{a}, P A R$, and VPD were the re- 
sponses variables, AFs was the treatment factor, and day and plant effects were considered random factors. Mean values were compared using Fisher's LSD post-hoc test $(\alpha=0.01)$. The assumptions of normality and homogeneity of variance were evaluated using an exploratory analysis of residuals. Sap flow models were then adjusted using the totality of the data recorded during the monitoring period ( $\mathrm{n}=3816$ measurements of sap flow in the four cacao plants of each AF). To predict $V_{s}$ (sap flow, dependent variable) based on microclimatic variables (predictor variables), new LMM were adjusted. Type of AF was included in the model as a dummy variable, and $R H_{a}, T_{a}, P A R$, and $V P D$ as predictors. The model for each AFs was:

$$
V_{s}=\beta_{0}+\beta_{1} R H_{a}+\beta_{2} T_{a}+\beta_{3} P A R+\beta_{4} V P D
$$

Bayesian Information Criterion (BIC) and Akaike Information Criterion (AIC) were used as criteria for the selection of the best model. Partial residuals were studied to verify the type of relationship (i.e., linear or quadratic) to be included between each microclimatic variable and the response variable. The adjustments to the LMM were made using the function $\operatorname{lm} e^{46}$ in the package $n l m e$ of R-Project version 3.6.0 $0^{47}$ and using the implemented interface of the R platform in InfoStat ${ }^{48}$.

Validation. A simple linear regression analysis was conducted between predicted values, generated using the best (AIC/BIC) model for sap flow, and a validation dataset $(n=1740)$. The $\mathrm{R}^{2}$ value was considered a measure of the predictive value of the model. We used the methodology of Vezy et al. ${ }^{49}$ to evaluate the goodness of fit of the model. In order to evaluate the mean precision of the model with the same units as the variable of interest, we calculated RMSE and bias. The modeling efficiency (EF), also known as Nash-Sutcliffe efficiency (NSE), was also used to describe how well the graph of observed versus simulated data fits in the identity function. A standard regression was used to describe the relative relationship between the observations and the simulation (slope), which allows us to identify any lag or deviation between the simulated and observed values. For this purpose, scatter plots were created showing the fit line and the best fit line (i.e., $y=x$ ). The goodness of fit of the model was evaluated using the function $g g o f^{50}$ in the package HydroGOF of R-Project version 3.6.0 $0^{47}$ and using the implemented interface of the R platform in InfoStat ${ }^{48}$.

\section{Results}

Sap flow variability under different radiation intensities. In the $H_{P A R}$ agroforestry system, the cacao plant exhibited increasing sap flows throughout the entire monitoring period, even at night (Fig. 3a). The maximum sap flow average values were $0.27 \pm 0.03 \mathrm{~L} \mathrm{~h}^{-1}$ during daylight hours and $0.0300 \pm 0.0023 \mathrm{~L} \mathrm{~h}^{-1}$ during the night. The AFs $M_{P A R}$ and $L_{P A R}$, however, exhibited negative sap flows at night, with average values of $0.0047 \pm 0.0085 \mathrm{~L} \mathrm{~h}^{-1}$ and $-0.0314 \pm 0.004 \mathrm{~L} \mathrm{~h}^{-1}$, respectively (Fig. 3a). For $M_{P A R}$ and $L_{P A R}$, nocturnal averages were significantly different from zero ( $\mathrm{t}$-test; $p<0.01$ ), which may indicate a differential nocturnal hydraulic redistribution across these agroforestry arrangements. When comparing sap flow under different intensities of sun radiation, sap flow was higher in $H_{P A R}$ compared to the treatments, with maximum values recorded at noon. Predicted values obtained from our LMM model closely resembled the observed data (Fig. 3a,b; see below).

Monitoring microclimatic variables in the AFs under study. The air relative humidity was, on average, $90 \%$ with a variation range between 49 and $100 \%$ (Table 2). The mean air temperature was $21.4^{\circ} \mathrm{C}$ at night and $28.1^{\circ} \mathrm{C}$ during the day. The mean $P A R$ value during the day was $708.9 \mu \mathrm{mol} \mathrm{m}^{-2} \mathrm{~s}^{-1}$, with a maximum value of $2310 \mu \mathrm{mol} \mathrm{m}^{-2} \mathrm{~s}^{-1}$. Mean $V P D$ was $0.28 \mathrm{kPa}$, with a maximum value of $1.86 \mathrm{kPa}$. As illustrated in Table 1 , the greatest differences between AF arrangements in all microclimatic variables occurred at 13:00 h (solar time) and were significant in every case $(p<0.01)$; differences between arrangements in all microclimatic variables were also recorded at 10:00 and 16:00 $\mathrm{h}(p<0.01)$. In the case of the $L_{P A R}$ arrangement, the average temperature at 13:00 $\mathrm{h}$ was $26.6^{\circ} \mathrm{C}$ - the minimum value recorded in any of the three intensities. On average, temperatures in $M_{P A R}$ and $H_{P A R}$ were $1.81^{\circ} \mathrm{C}$ and $3.12^{\circ} \mathrm{C}$ higher, respectively (Table 1). There were also differences in all microclimatic variables during the night, and these differences were significant in all cases $(p<0.01)$; specifically, at 04:00 $\mathrm{h}$, there were significant differences for $T_{a}$ and $V P D$ between agroforestry systems.

For the remaining variables, differences between agroforestry arrangements followed similar patterns. The lowest values of transmitted $P A R$ and $V P D$ were recorded in $L_{P A R}$, where there is a denser companion tree canopy; the highest values were recorded in $H_{P A R}$, and intermediate values in $M_{P A R}$. Relative humidity followed the opposite pattern (maximum in $L_{P A R}$, minimum in $H_{P A R}$ ). We noticed that the PAR values at 13:00 $\mathrm{h}$ in the $H_{P A R}$ arrangement $\left(2279 \mu \mathrm{mol} \mathrm{m} \mathrm{m}^{-2} \mathrm{~s}^{-1}\right)$ had an mean value higher than those values obtained in the other two arrangements (Table 2; Fig. 4). When relating the sap flow values measured in the different plots to the different microclimatic variables, we found a negative correlation between $V_{s}$ and $R H_{a}$, and a positive correlation between $V_{s}$ on the one hand, and $P A R, T_{a}$ and $V P D$ on the other (all had correlation coefficients greater than 0.73 in general terms, and greater than 0.78 within each plot, ranked $\left.\mathrm{r}\left(V_{s}, P A R\right)>\mathrm{r}\left(V_{s}, V P D\right)>\mathrm{r}\left(V_{s}, T_{a}\right)\right)$ (Table 3$)$.

Modelling sap flow $\left(\mathbf{V}_{s}\right)$ under different radiation intensities. The general model which estimated the relationship between observed versus predicted $V_{s}$ for all three AFs, showed that the estimate was very close to the $y=x$ line (Fig. $5 \mathrm{a}-\mathrm{c}$ ). The model allowed us to explain the diurnal behavior of sap flow, which was affected by the microclimatic variables within each agroforestry arrangement that, in turn, impacted the incident radiation intensity that reached the plot. Specifically, the model predicted the water use of the cacao crop as a function of time, replicating phenomena such as hydraulic redistribution (HR). Indeed, $V_{s}$ was predicted well by the statistical model $\left(R^{2}=0.98\right)$ that included the microclimatic regressors and exhibited significant differences between the three different AFs (Tables 4,5). Significant differences were found between the slopes of all 

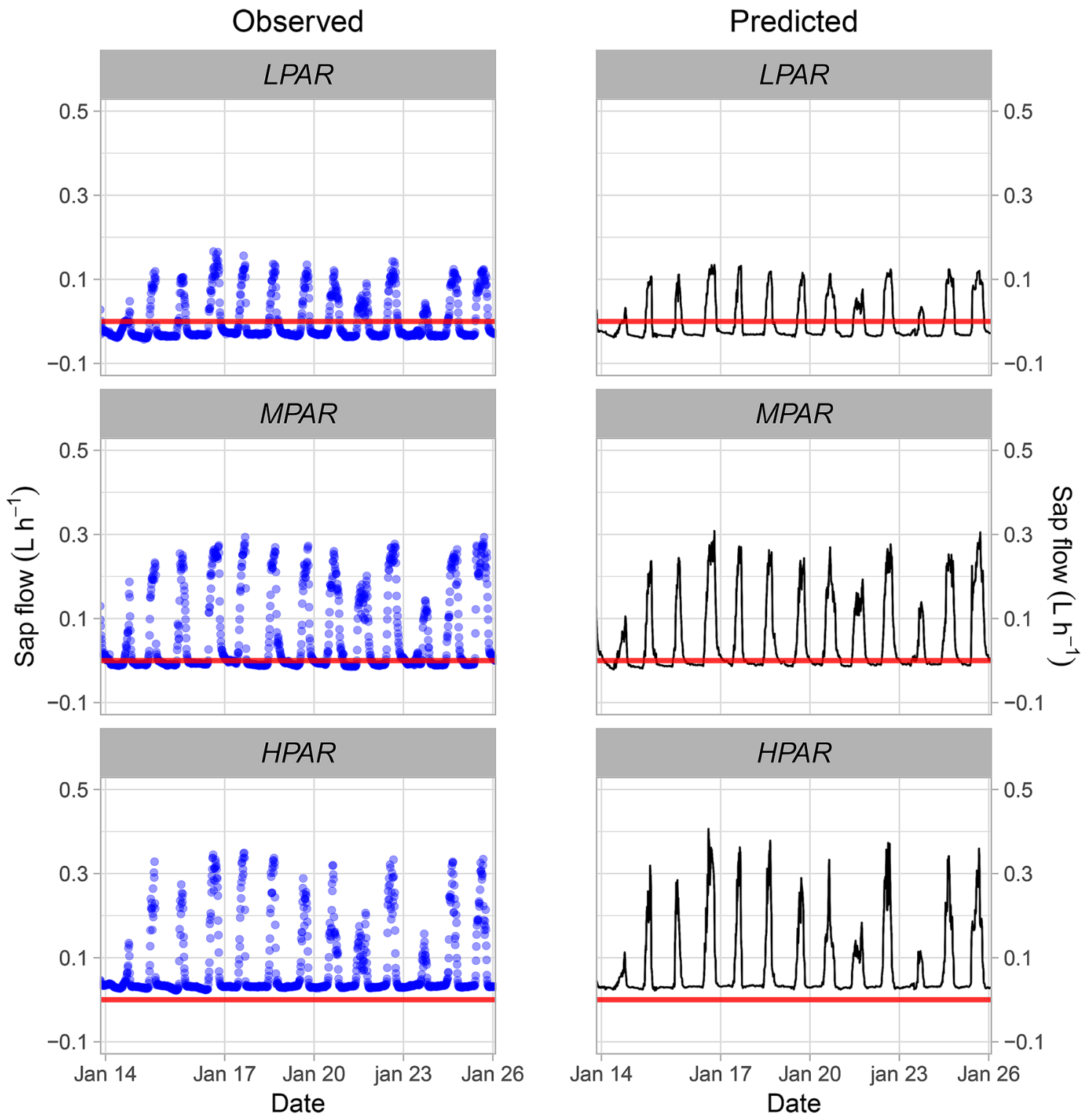

Figure 3. Diurnal pattern of sap flow of cacao plants under different agroforestry arrangements: (a) observed, and (b) predicted sap flow based on the LMM model. The agroforestry arrangements are described in the methods section and Fig. 2.

AFs for each microclimatic variable $\left(R H_{a}, T_{a}, P A R, V P D\right)$, with values of $p<0.01$ except for $T_{a}$ between $H_{P A R}$ and $M_{P A R}(p>0.05)$. Differences in intercepts were also observed depending on the AFs $(p<0.01)$. When analyzing the behavior of $V_{s}$ and the process of $\mathrm{HR}$, we found that the microclimatic variables that determine this phenomenon were the $R H_{\mathrm{a}}$ and $V P D$. This was due to the negative slopes in the model for both $R H_{\mathrm{a}}$ and $V P D$ in the radiation intensities $M_{P A R}$ and $L_{P A R}$, which were statistically different from $H_{P A R}$.

An analysis of the predicted values versus the observed values produced a coefficient of determination of $\mathrm{R}^{2}=0.95$ for $H_{P A R}$ (Fig. 5a), 0.96 for $M_{P A R}$ (Fig. 5b), and 0.98 for $L_{P A R}$ (Fig. 5c). All $\mathrm{R}^{2}$ values were highly significant $(p<0.0001)$. These results indicate that the proposed modelling approach predicted the behavior of sap flow fairly well in relation to microclimatic variables of different radiation intensities (i.e., agroforestry arrangements), with the coefficient of determination being equal or greater than 0.95 for all AFs (Fig. 5). In all AFs (or radiation intensities), the regression line was a bit below the line $\mathrm{y}=\mathrm{x}$ for high $V_{s}$ values and a bit above it for low $V_{s}$ values (Fig. 5). When analyzing the relationship between observed and fitted values for the model, the RMSE ranged from 0.01 to $0.02 \mathrm{~L} \mathrm{~h}^{-1}$ for the different radiation intensities or AFs (Fig. 5). Likewise, the slope of the regression of the predicted vs. observed values in the different radiation intensities was statistically different from the reference slope $(\mathrm{y}=\mathrm{x})$ for all AFs (Fig. 5). This means that, in general terms, the model overestimates the values of $V_{s}$ by an average of $2.8 \%$. 


\begin{tabular}{|c|c|c|c|c|c|c|c|c|c|c|c|c|c|c|c|c|c|}
\hline \multirow[b]{2}{*}{ Hour } & \multirow[b]{2}{*}{ Arrangement } & \multicolumn{4}{|l|}{$R H_{a}$} & \multicolumn{4}{|l|}{$T_{a}$} & \multicolumn{4}{|l|}{$P A R$} & \multicolumn{4}{|l|}{ VPD } \\
\hline & & Mean & & S.E & & Mean & & S.E & & Mean & & S.E & & Mean & & S.E & \\
\hline \multicolumn{18}{|l|}{ Day } \\
\hline \multirow{3}{*}{ 10:00 } & $L_{P A R}$ & 88.32 & \pm & 1.91 & $\mathrm{a}$ & 23.98 & \pm & 0.43 & c & 354.51 & \pm & 38.66 & $\mathrm{~b}$ & 0.30 & \pm & 0.05 & b \\
\hline & $M_{P A R}$ & 81.69 & \pm & 2.66 & $\mathrm{~b}$ & 25.88 & \pm & \begin{tabular}{|l|}
0.49 \\
\end{tabular} & $\mathrm{~b}$ & 446.25 & \pm & 51.58 & $\mathrm{~b}$ & 0.53 & \pm & 0.08 & $\mathrm{a}$ \\
\hline & $H_{P A R}$ & 80.26 & \pm & 3.18 & $\mathrm{~b}$ & 26.87 & \pm & 0.67 & $\mathrm{a}$ & 1426.98 & \pm & 216.07 & $\mathrm{a}$ & 0.56 & \pm & 0.10 & $\mathrm{a}$ \\
\hline \multirow{3}{*}{ 13:00 } & $L_{P A R}$ & 76.56 & \pm & 2.69 & $\mathrm{a}$ & 26.63 & \pm & \begin{tabular}{|l|}
0.64 \\
\end{tabular} & c & 467.67 & \pm & 45.80 & $\mathrm{~b}$ & \begin{tabular}{|l|}
0.69 \\
\end{tabular} & \pm & \begin{tabular}{|l|}
0.09 \\
\end{tabular} & c \\
\hline & $M_{P A R}$ & 69.16 & \pm & 3.10 & $\mathrm{~b}$ & 28.44 & \pm & 0.67 & $\mathrm{~b}$ & 559.43 & \pm & 51.88 & $\mathrm{~b}$ & 1.00 & \pm & 0.12 & $\mathrm{~b}$ \\
\hline & $H_{P A R}$ & 67.94 & \pm & 3.45 & $\mathrm{~b}$ & 29.75 & \pm & 0.80 & $\mathrm{a}$ & \begin{tabular}{|l|l|}
2278.98 \\
\end{tabular} & \pm & \begin{tabular}{|l|}
275.40 \\
\end{tabular} & $\mathrm{a}$ & 1.12 & \pm & 0.15 & $\mathrm{a}$ \\
\hline \multirow{3}{*}{$16: 00$} & $L_{P A R}$ & 80.11 & \pm & 3.49 & $\mathrm{a}$ & 26.25 & \pm & 0.86 & c & 216.88 & \pm & 37.74 & $\mathrm{~b}$ & \begin{tabular}{|l|}
0.61 \\
\end{tabular} & \pm & 0.13 & $\mathrm{~b}$ \\
\hline & $M_{P A R}$ & 76.51 & \pm & 4.02 & c & 27.03 & \pm & \begin{tabular}{|l|}
0.81 \\
\end{tabular} & $\mathrm{~b}$ & 238.44 & \pm & 38.69 & $\mathrm{~b}$ & 0.75 & \pm & 0.15 & $\mathrm{a}$ \\
\hline & $H_{P A R}$ & 78.24 & \pm & 3.93 & $\mathrm{~b}$ & 27.47 & \pm & \begin{tabular}{|l|}
0.89 \\
\end{tabular} & $\mathrm{a}$ & 778.36 & \pm & 148.99 & $\mathrm{a}$ & \begin{tabular}{|l|l|}
0.71 \\
\end{tabular} & \pm & 0.14 & $\mathrm{a}$ \\
\hline \multicolumn{18}{|l|}{ Night } \\
\hline \multirow{3}{*}{ 20:00 } & $L_{P A R}$ & 97.86 & \pm & \begin{tabular}{|l|l|}
0.19 \\
\end{tabular} & $\mathrm{a}$ & 23.04 & \pm & \begin{tabular}{|l|l|}
0.17 \\
\end{tabular} & $a$ & & & & & \begin{tabular}{|l|}
0.05 \\
\end{tabular} & \pm & 0.01 & b \\
\hline & $M_{P A R}$ & 95.57 & \pm & \begin{tabular}{|l|}
0.37 \\
\end{tabular} & $\mathrm{~b}$ & 23.27 & \pm & 0.12 & $\mathrm{a}$ & & & & & 0.11 & \pm & 0.01 & $\mathrm{a}$ \\
\hline & $H_{P A R}$ & 95.06 & \pm & 0.38 & $\mathrm{~b}$ & 23.65 & \pm & 0.12 & $\mathrm{~b}$ & & & & & 0.12 & \pm & 0.01 & $\mathrm{a}$ \\
\hline \multirow{3}{*}{ 00:00 } & $L_{P A R}$ & 99.47 & \pm & \begin{tabular}{|l|}
0.08 \\
\end{tabular} & $\mathrm{a}$ & 21.99 & \pm & 0.16 & $\mathrm{a}$ & & & & & \begin{tabular}{|l|}
0.01 \\
\end{tabular} & \pm & \begin{tabular}{|l|}
0.01 \\
\end{tabular} & $\mathrm{~b}$ \\
\hline & $M_{P A R}$ & 98.41 & \pm & 0.22 & $\mathrm{~b}$ & 22.43 & \pm & 0.12 & $\mathrm{~b}$ & & & & & 0.04 & \pm & 0.01 & $\mathrm{a}$ \\
\hline & $H_{P A R}$ & 98.03 & \pm & 0.18 & $\mathrm{~b}$ & 22.79 & \pm & 0.12 & $\mathrm{~b}$ & & & & & \begin{tabular}{|l|l|}
0.05 \\
\end{tabular} & \pm & \begin{tabular}{|l|}
0.01 \\
\end{tabular} & $\mathrm{a}$ \\
\hline \multirow{3}{*}{ 04:00 } & $L_{P A R}$ & \begin{tabular}{|l|l|}
99.84 \\
\end{tabular} & \pm & \begin{tabular}{ll|}
0.05 \\
\end{tabular} & $\mathrm{a}$ & 21.48 & \pm & 0.13 & $\mathrm{a}$ & & & & & \begin{tabular}{|l|l|}
0.00 \\
\end{tabular} & \pm & 0.00 & $\mathrm{a}$ \\
\hline & $M_{P A R}$ & 99.35 & \pm & \begin{tabular}{|l|l|}
0.09 \\
\end{tabular} & $\mathrm{~b}$ & 22.21 & \pm & 0.11 & $\mathrm{a}$ & & & & & \begin{tabular}{|l|l|}
0.01 \\
\end{tabular} & \pm & \begin{tabular}{|l|l|}
0.01 \\
\end{tabular} & $\mathrm{~b}$ \\
\hline & $H_{P A R}$ & 99.03 & \pm & \begin{tabular}{|l|l|}
0.09 \\
\end{tabular} & c & 22.44 & \pm & \begin{tabular}{|l|l|}
0.10 \\
\end{tabular} & $\mathrm{~b}$ & & & & & 0.05 & \pm & \begin{tabular}{|l|}
0.01 \\
\end{tabular} & c \\
\hline
\end{tabular}

Table 2. Mean values $\pm \mathrm{SE}$ of the microclimatic variables during the monitoring period under different radiation intensities and at different hours of the day (official hours UTC/GMT-5:00 h): air relative humidity $\left(R H_{a}, \%\right)$, air temperature $\left(T_{a},{ }^{\circ} \mathrm{C}\right)$, photosynthetically active radiation $\left(P A R, \mu \mathrm{mol} \mathrm{m} \mathrm{m}^{-2} \mathrm{~s}^{-1}\right)$, vapor pressure deficit $(V P D, \mathrm{kPa})$. The agroforestry arrangements are described in the methods section and Fig. 2 . Values in a column that have different letters within the same time slot indicate significant differences between AFs (posthoc LSD tests, $p<0.05)$.

\section{Discussion}

This study presents a model that empirically determines the relationship between different microclimatic variables $\left(P A R, T_{a}, R H_{a}\right.$, and $\left.V P D\right)$ and diurnal sap flow patterns in cacao plants under different agroforestry arrangements in the continental Amazon region. These arrangements mainly differed in their intensity of incident radiation on the cacao crop. Incident radiation had a direct impact on microclimatic conditions that greatly differed between AFs. There are few models that include a set of microclimatic variables to predict diurnal patterns of cacao sap flow. Studies such as those developed by Köhler et al. ${ }^{17}$ in Indonesia have also found that different microclimatic variables have significant effects on $V_{s}$ in cacao plantations under different levels of sun radiation. The Köhler et al. ${ }^{17}$ modeling results were derived from a Jarvis-type sap flow model that found differences in sap flow response to changes in both vapor pressure deficit and radiation. The same occurred in López et al. ${ }^{51}$ in Mexico, which found that variations in temperature and sun radiation significantly affected transpiration rates (and thus, sap flow rates) when there were variations in cloud cover. Studies conducted by Abdulai et al..$^{52}$ in Ghana showed the diurnal water use of the cacao crop as well as the average diurnal sap flow density, but did not specifically describe the use of models derived from environmental variables to predict sap flow. Overall, by predicting the diurnal pattern of cacao sap flow, the results from this type of modeling approach can also be used to obtain the diurnal patterns of transpiration and canopy conductance of cacao plants using the inverted Penman-Monteith equation as reported in different studies ${ }^{14-16}$.

Our model determined the relation between different microclimatic conditions and cacao sap flow during the relative dry season in the Amazonian region, a period of great agronomic importance for fruit set and cacao pod production. The prediction of sap flow and water relations of cacao crops during this relatively dry season is of great economic importance. The production of cacao beans depends largely on the amount and quality of the flowers during the blooming season ${ }^{53}$, which in the continental Amazonian region occurs at the end of this relatively dry, hot period ${ }^{35,54,55}$. Cacao plants tend to be particularly active during this season and display high photosynthetic rates in order to bloom appropriately. However, unlike other cacao producing tropical regions with high diurnal insolation, the average sunshine duration in the continental Amazon is only 3-4 h per day ${ }^{56}$, due to its high cloud cover. This situation causes different shade configurations in cacao agroforestry systems ${ }^{57}$ and, in turn, variations in microclimatic conditions ${ }^{58}$. These variations greatly affect cacao production ${ }^{15}$, particularly under the more shaded AF arrangements.

Our results showed that increases in $P A R$ and $V P D$ were positively correlated with sap flow values, while this correlation was negative between $V_{s}$ and $R H_{a}$. This indicates that microclimatic variables decisively influenced the quantity and direction of $V_{s}$ during both day and night. The effect of the microclimatic conditions was modified by the upper tree canopy and plant density, which determined variations and differences in the pattern of 

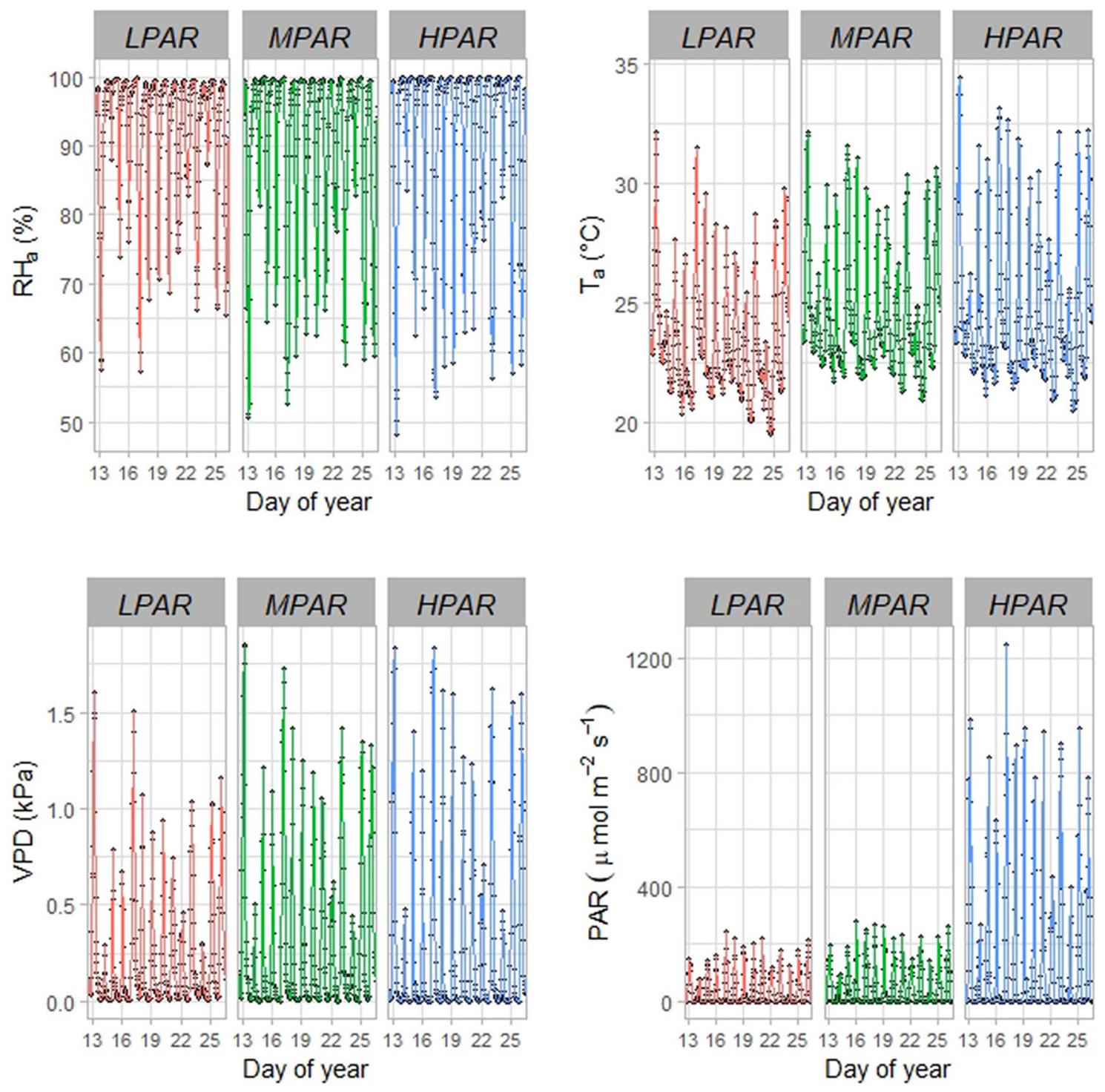

Figure 4. Diurnal patterns of air relative humidity $\left(R H_{a}\right)$; air temperature $\left(T_{a}\right)$; vapor pressure deficit $(V P D)$; and photosynthetically active radiation $(P A R)$ under different agroforestry arrangements during the period of study. Types of AFs and legend are described in the methods section and in Fig. 2.

\begin{tabular}{|l|l|l|l|l|}
\hline Factor & $\boldsymbol{R H}_{\boldsymbol{a}}$ & $\boldsymbol{T}_{\boldsymbol{a}}$ & $\boldsymbol{P A R}$ & $\boldsymbol{V P D}$ \\
\hline General & -0.78 & 0.73 & 0.75 & 0.77 \\
\hline$L_{P A R}$ & -0.87 & 0.78 & 0.91 & 0.84 \\
\hline$M_{P A R}$ & -0.93 & 0.90 & 0.90 & 0.92 \\
\hline$H_{P A R}$ & -0.92 & 0.88 & 0.93 & 0.92 \\
\hline
\end{tabular}

Table 3. Pearson correlation coefficients between $V_{s}$ in cacao plants and microclimatic variables during the monitoring period under different radiation intensities. Types of AFs are described in the methods section and in Fig. 2. The microclimatic variables are: air relative humidity $\left(R H_{a}\right)$; air temperature $\left(T_{a}\right)$; photosynthetically active radiation $(P A R)$; and vapor pressure deficit $(V P D)$. All correlation coefficients were highly significant $(p<0.0001)$.

$V_{s}$ in each AF. The model accurately predicted $V_{s}$ patterns at times during the day when sap flow was positive (i.e., flowed from the root system to the main trunk and branches). This prediction was particularly accurate for $H_{P A R}$ during the entire monitoring period, where $V_{s}$ increased from $0.039 \mathrm{~L} \mathrm{~h}^{-1}$ in the cacao tree trunk from 8:00 $\mathrm{h}$ until noon, reached its maximum level at $13: 00 \mathrm{~h}\left(0.228 \mathrm{~L} \mathrm{~h}^{-1}\right)$, and decreased to $0.031 \mathrm{~L} \mathrm{~h}^{-1}$ in the afternoon. This behavior was similar to that reported by Köhler et al. ${ }^{17}$ and López et al. ${ }^{51}$ for cacao trees in AFs under tropical wet climates in Indonesia and Mexico, respectively. The positive and more voluminous sap flow in $H_{P A R}$ as 


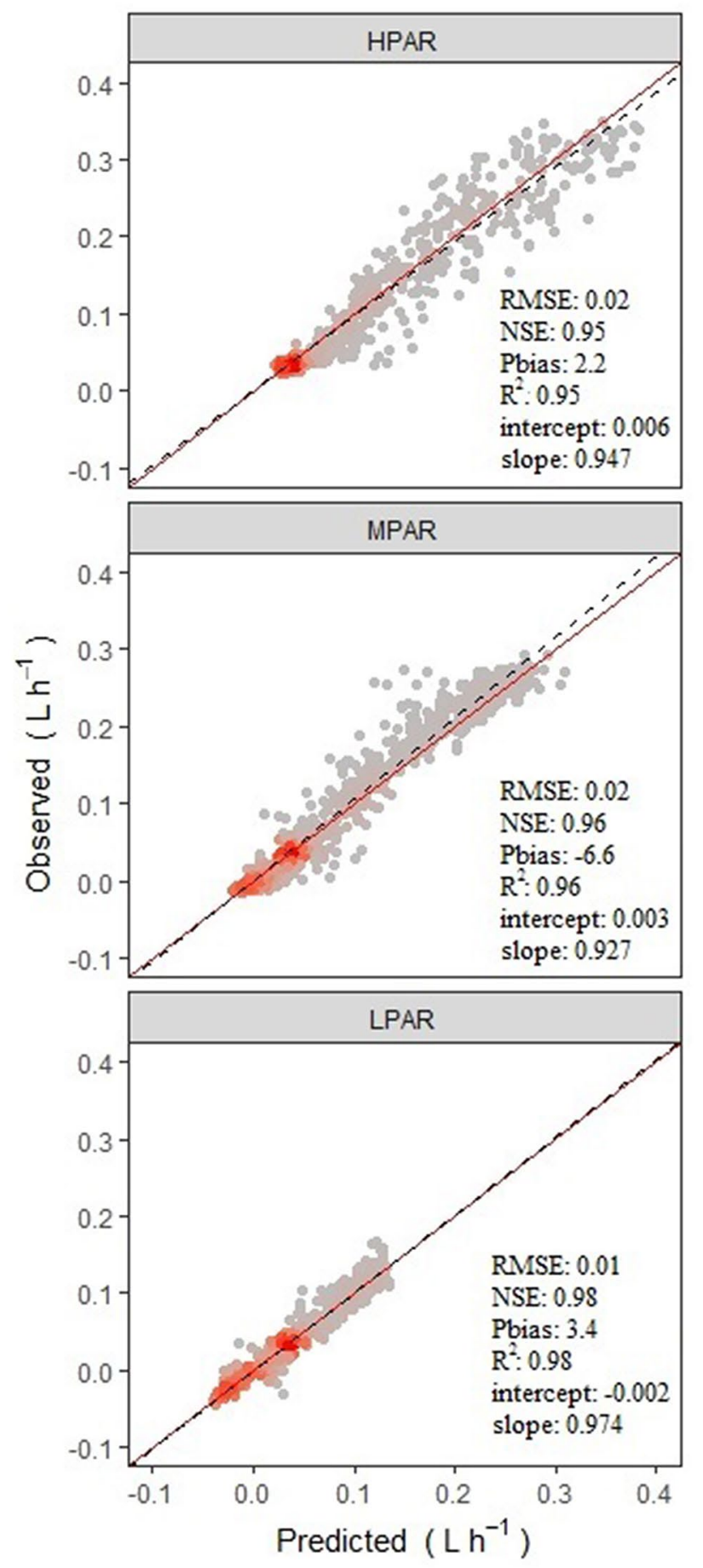

Figure 5. Regression line between observed $V_{s}$ (y-axis) versus predicted $V_{s}$ (x-axis) obtained from the LMM model for each agroforestry system $(p<0.0001$ in all cases) are shown as dotted lines (red line represents $\mathrm{y}=\mathrm{x}$ ). The Root Mean Square Error (RMSE), Nash-Sutcliffe efficiency (NSE), Percent Bias (Pbias), and coefficient of determination $\left(\mathrm{R}^{2}\right)$ are given. Colors represent a gradient of density of the points from grey (the lowest) to red (the highest). Types of AFs and their legend are described in the methods section and in Fig. 2.

compared to the other AFs suggests that air conditions (and probably soil humidity) were optimal at the high levels of radiation present in $H_{P A R}$, which was directly related to the high demand for water of cacao trees so as to be physiologically active and perform photosynthesis ${ }^{36}$. In fact, the maximum photosynthetic rates in cacao trees in $H_{P A R}$ were significantly higher than those in cacao trees in the $M_{P A R}$ and $L_{P A R} \mathrm{AFs}^{57}$.

Besides predicting the positive sap flow in cacao plants and its differences between agroforestry arrangements, our model was also able to predict inverse or basipetal flows during the night. This inverse flow (from the main 


\begin{tabular}{|l|l|l|l|l|r|}
\hline & Value & & Std. Error & t-value & $p$ value \\
\hline$H_{P A R}$ & 0.14904 & \pm & 0.02786 & 534.879 & $<0.0001$ \\
\hline$M_{P A R}$ & 0.37090 & \pm & 0.03559 & 1.042 .063 & $<0.0001$ \\
\hline$L_{P A R}$ & -0.04641 & \pm & 0.02349 & -197.595 & 0.0482 \\
\hline$M_{\text {PAR }}$ vs $L_{\text {PAR }}$ & 0.41732 & \pm & 0.02908 & 20.592 .275 & $<0.0001$ \\
\hline$R H_{a} H_{P A R}$ & -0.00059 & \pm & 0.00022 & -272.954 & 0.0064 \\
\hline$M_{P A R}$ & -0.00409 & \pm & 0.00033 & -1.249 .385 & $<0.0001$ \\
\hline$L_{P A R}$ & -0.00057 & \pm & 0.00021 & -265.782 & 0.0079 \\
\hline$M_{P A R} v s L_{P A R}$ & -0.00352 & \pm & 0.00027 & 17.127 .910 & $<0.0001$ \\
\hline$T_{a} H_{P A R}$ & -0.00258 & \pm & 0.00046 & -558.407 & $<0.0001$ \\
\hline$M_{P A R}$ & -0.00043 & \pm & 0.00036 & -119.058 & 0.2339 \\
\hline$L_{P A R}$ & 0.00178 & \pm & 0.00027 & 658.568 & $<0.0001$ \\
\hline$M_{P A R} v s L_{P A R}$ & -0.00220 & \pm & 0.00030 & 5.416 .543 & $<0.0001$ \\
\hline$P A R H_{P A R}$ & 0.00007 & \pm & 0.00001 & 1.460 .565 & $<0.0001$ \\
\hline$M_{P A R}$ & 0.00050 & \pm & 0.00001 & 3.558 .999 & $<0.0001$ \\
\hline$L_{P A R}$ & 0.00001 & \pm & 0.00001 & 0.94846 & 0.3430 \\
\hline$M_{P A R}$ vs $L_{P A R}$ & 0.00049 & \pm & 0.00001 & 135.358 .210 & $<0.0001$ \\
\hline$V P D H_{P A R}$ & 0.12195 & \pm & 0.00697 & 1.749 .240 & $<0.0001$ \\
\hline$M_{P A R}$ & -0.07844 & \pm & 0.01113 & -704.621 & $<0.0001$ \\
\hline$L_{P A R}$ & -0.06120 & \pm & 0.00721 & -849.277 & $<0.0001$ \\
\hline$M_{P A R}$ vs $L_{P A R}$ & -0.01724 & \pm & 0.00913 & 356.462 & 0.0591 \\
\hline
\end{tabular}

Table 4. Coefficients of the best model (according with AIC and BIC criterion) predicting sap flow $\left(V_{s}\right)$ as a function of a set of microclimatic variables across the different radiation intensities for cacao plantations in the Colombian Amazon. The types of AFs and legend are described in the methods section and Fig. 2. The microclimatic variables are: air relative humidity $\left(R H_{a}, \%\right)$; air temperature $\left(T_{a},{ }^{\circ} \mathrm{C}\right)$; photosynthetically active radiation $\left(P A R, \mu \mathrm{mol} \mathrm{m} \mathrm{m}^{-2} \mathrm{~s}^{-1}\right)$; and vapor pressure deficit $(V P D, \mathrm{kPa})$. The types of $\mathrm{AF}$ were included as dummy variables in the regression model to control for potentially effects of different agroforestry arrangements and incident radiation intensities on microclimatic variables and sap flow across AFs. The first three coefficients (Value) shown in the table are: the value for $H_{P A R}$ corresponds to $\beta_{0}$ (see Eq. 3 ) in $H_{P A R}$, the value for $M_{P A R}$ corresponds to the difference between $H_{P A R}-\beta_{0}$ and $M_{P A R}-\beta_{0}$, the value for $L_{P A R}$ corresponds to the difference between $H_{P A R}-\beta_{0}$ and $L_{P A R^{-}}-\beta_{0}$. The following groups of coefficients (row blocks separated by a line) correspond to the coefficients for each microclimatic variable and is interpreted in the same way as described above but applied to the partial slope for each microclimatic variable. In all cases, the $M_{P A R}$ vs $L_{P A R}$ rows show the difference between their estimated coefficients.

\begin{tabular}{|l|l|l|l|}
\hline Coefficients & $\boldsymbol{H}_{P A R}$ & $\boldsymbol{M}_{P A R}$ & $\boldsymbol{L}_{P A R}$ \\
\hline$\beta_{0}$ & 0.14904 & 0.37090 & -0.04641 \\
\hline$R H_{a}$ & -0.00059 & -0.00468 & -0.00116 \\
\hline$T_{a}$ & -0.00258 & -0.00301 & -0.0008 \\
\hline$P A R$ & 0.00007 & 0.00057 & 0.00008 \\
\hline$V P D$ & 0.12195 & 0.04351 & 0.06075 \\
\hline
\end{tabular}

Table 5. Coefficients of the model (see Eq. 3) for the determination of $V_{s}$ of cacao trees using microclimatic variables under different radiation intensities as predictors. Types of AF are described in the methods section and in Fig. 2. Microclimatic variables are: air relative humidity $\left(R H_{a} ; \%\right)$; air temperature $\left(T_{a}\right.$; $\left.{ }^{\circ} \mathrm{C}\right)$; photosynthetically active radiation $\left(P A R ; \mu \mathrm{mol} \mathrm{m}{ }^{-2} \mathrm{~s}^{-1}\right)$; and vapor pressure deficit (VPD; $\left.\mathrm{kPa}\right)$. Coefficient values were calculated using results in Table $4 . \beta_{0}$ is the intercept.

trunk to the roots and potentially to the soil) was measured in the agroforestry arrangements $L_{P A R}$ and $M_{P A R}$, which exhibited values of -0.04 and $-0.01 \mathrm{~L} \mathrm{~h}^{-1}$ during the night, respectively. Basipetal sap flow has been extensively described by Burgess et al. ${ }^{59}$ and many others, who consider this phenomenon to be directly related to plant hydraulic redistribution. Hydraulic redistribution is considered indicative of a passive process of sap movement in the direction of the maximum difference in water potential between the parts of the plant (branches, trunk, roots) and the soil ${ }^{59,60}$. In the $L_{P A R}$ and $M_{P A R}$ arrangements, it is possible that the cacao plants had a higher water potential (closer to zero) during the night than the surface soil layers, which may have dried during the day due to water uptake by the whole plant community of the AF and soil water evaporation. Soils in these shaded AFs might have been drier than in $H_{P A R}$ (where there was more incident radiation, a higher temperature, and potentially more evaporation in the soil than in $L_{P A R}$ and $M_{P A R}$ ), probably due to the great demand for water 
by the companion plant species that make up the shade canopy in $L_{P A R}$ and $M_{P A R}$. Our results showed that the higher the density of companion plants $\left(L_{P A R}>M_{P A R}>H_{P A R}\right)$, the greater the hydraulic redistribution observed, suggesting there was a depletion in surface soil water content with increasing plant density. In fact, results from other studies support this idea, as soil humidity data measured in the same AFs during the dry season showed that surface soil profiles in the $L_{P A R}$ and $M_{P A R}$ AFs were, on average, drier than $H_{P A R}{ }^{61}$. Moreover, the fact that our sap flow predictive models differed across AFs suggests that soil water content not only differed among AFs but also modulated cacao sap flow dynamics.

For this plant hydraulic distribution to occur, it is necessary that nocturnal transpiration stops or vastly decreases; in such cases, the highest water potential gradient in the plant soil continuum may be between the wet soil profiles and drier surface soil layers ${ }^{62}$ and, potentially, from the trunk to the roots ${ }^{63}$. Low VPD values (e.g., fog and cloudy nights with a high $R H_{a}$ ) may impair nocturnal transpiration ${ }^{62}$, creating favorable conditions for water to be redistributed into dry soils. Our results align with this idea: in $L_{P A R}$ and $M_{P A R}$, unlike in $H_{P A R}$, there were low levels of $V P D$ and very high levels of $R H_{a}$, which likely inhibited the nocturnal transpiration of cacao plants, allowing the preferential sap flow to occur from the plant to the relatively drier surface soil profile. The diurnal proportion of reversed $V_{s}$ (i.e., the proportion of flow that went from the plant tissue to the roots and, potentially, on to the soil) was $49.3 \%$ in $L_{P A R}$ and $5.08 \%$ in $M_{P A R}$; these values fall within the range reported by other authors $^{63,64}$ for other forest species. This ability of cacao to redistribute water is probably relevant to reduced competition for surface water with the companion species the next day, allowing cacao trees from $L_{P A R}$ and $M_{P A R}$ to be physiologically active during the next day. Instead, and like $L_{P A R}$ and $M_{P A R}$, the positive nocturnal sap flow exhibited by cacao trees in $H_{P A R}$ is probably indicative of significant plant nocturnal transpiration, which usually inhibits hydraulic redistribution ${ }^{60,65}$. Significant nocturnal transpiration indicates that the maximum gradient of water potential for cacao plants in $H_{P A R}$ would have been between the soil profile to the roots, and from the roots to the leaves and atmosphere, preventing (or reducing) hydraulic redistribution ${ }^{66}$.

\section{Conclusions}

The different cacao agroforestry arrangements, which differed in their structure and density of shade canopy plants, generated different incident radiation intensities, modifying the microclimatic conditions in each plantation and directly affecting diurnal patterns of sap flow in cacao trees. We accurately modelled sap flow as a function of a set of microclimatic variables, including PAR, VPD, $\mathrm{RH}_{\mathrm{a}}$, and temperature in each $\mathrm{AF}$, and accurately modelled the differences in sap flow across AFs. Nonetheless, and regardless of the type of agroforestry arrangement, the variable with the greatest effect on cacao $V_{s}$ was $P A R$ (and thus, incident radiation), which also modulated $\mathrm{RH}_{\mathrm{a}}$ and $\mathrm{T}_{\mathrm{a}}$ values, having all an effect on $V P D$. The model can also track plant phenomena such as nocturnal transpiration (in $H_{P A R}$ ) and inverse nocturnal sap flow indicative of hydraulic redistribution (in $M_{P A R}$ and $\left.L_{P A R}\right)$ and, thus, could be a useful tool for managing and predicting cacao tree water use as a function of the microclimatic conditions in the different agroforestry arrangements in the Continental Amazon rainforest region.

Received: 30 December 2019; Accepted: 19 April 2021

Published online: 18 May 2021

\section{References}

1. ICCO. ICCO quarterly bulletin of cocoa statistics. The International Cocoa Organization (ICCO) Cocoa Producing and Cocoa Consuming Countries. (2020).

2. FAOSTAT. Datos sobre alimentación y agricultura. Organización de las Naciones Unidas para la Alimentación y la Agricultura (2020).

3. Afriyie-Kraft, L., Zabel, A. \& Damnyag, L. Adaptation strategies of Ghanaian cocoa farmers under a changing climate. For. Policy Econ. 113, 102115 (2020).

4. Abdulai, I. et al. Variations in yield gaps of smallholder cocoa systems and the main determining factors along a climate gradient in Ghana. Agric. Syst. 181, 102812 (2020).

5. Oyekale, A. S., Bolaji, M. B. \& Olowa, O. W. The effects of climate change on cocoa production and vulnerability assessment in Nigeria. Agric. J. 4, 77-85 (2009).

6. Ordoñez, C., Suárez, J. C., Rangel, J. O. \& Saavedra Mora, D. Los sistemas agroforestales y la incidencia sobre el estatus hídrico en árboles de cacao. Biotecnol. en el Sect. Agropecu. y Agroindustrial 19, 256-267 (2020).

7. Carr, M. K. V. \& Lockwood, G. The water relations and irrigation requirements of cocoa (Theobroma cacao L.): A review. Exp. Agric. 47, 653-676 (2011).

8. Balasimha, D., Apshara, E. \& Jose, C. Genotypic variations in chlorophyll fluorescence and stomatal conductance of cocoa in relation to drought tolerance Genetic resources management of cocoa View project Statistical investigation on plantation crops View project. J. Plant. Crop. 41, 40-45 (2013).

9. Abdulai, I. et al. Characterization of cocoa production, income diversification and shade tree management along a climate gradient in Ghana. PLoS ONE 13, e0195777 (2018).

10. Asare, R., Markussen, B., Asare, R. A., Anim-Kwapong, G. \& Ræbild, A. On-farm cocoa yields increase with canopy cover of shade trees in two agro-ecological zones in Ghana. Clim. Dev. 11, 435-445 (2019).

11. Somarriba, E. et al. Mainstreaming Agroforestry in Latin America 429-453 (Springer, Dordrecht, 2012). https://doi.org/10.1007/ 978-94-007-4676-3_21.

12. Bai, Y., Li, X., Liu, S. \& Wang, P. Modelling diurnal and seasonal hysteresis phenomena of canopy conductance in an oasis forest ecosystem. Agric. For. Meteorol. 246, 98-110 (2017).

13. Fu, S., Sun, L. \& Luo, Y. Canopy conductance and stand transpiration of Populus simonii Carr in response to soil and atmospheric water deficits in farmland shelterbelt, Northwest China. Agrofor. Syst. 91, 1165-1180 (2017).

14. Fu, S., Sun, L. \& Luo, Y. Combining sap flow measurements and modelling to assess water needs in an oasis farmland shelterbelt of Populus simonii Carr in Northwest China. Agric. Water Manag. 177, 172-180 (2016).

15. Schwendenmann, L. et al. Effects of an experimental drought on the functioning of a cacao agroforestry system, Sulawesi, Indonesia. Glob. Change Biol. 16, 1515-1530 (2010).

16. Köhler, M., Dierick, D., Schwendenmann, L. \& Hölscher, D. Water use characteristics of cacao and Gliricidia trees in an agroforest in Central Sulawesi, Indonesia. Ecohydrology 2, 520-529 (2009). 
17. Köhler, M., Hanf, A., Barus, H., Hendrayanto, \& Hölscher, D. Cacao trees under different shade tree shelter: Effects on water use. Agrofor. Syst. 88, 63-73 (2014).

18. Köhler, M., Schwendenmann, L. \& Hölscher, D. Throughfall reduction in a cacao agroforest: Tree water use and soil water budgeting. Agric. For. Meteorol. 150, 1079-1089 (2010).

19. Siles, P., Harmand, J. M. \& Vaast, P. Effects of Inga densiflora on the microclimate of coffee (Coffea arabica L.) and overall biomass under optimal growing conditions in Costa Rica. Agrofor. Syst. 78, 269-286 (2010).

20. Van Kanten, R. \& Vaast, P. Transpiration of arabica coffee and associated shade tree species in sub-optimal, low-altitude conditions of Costa Rica. Agrofor. Syst. 67, 187-202 (2006).

21. Dauzat, J., Rapidel, B. \& Berger, A. Simulation of leaf transpiration and sap flow in virtual plants: Model description and application to a coffee plantation in Costa Rica. Agric. For. Meteorol. 109, 143-160 (2001).

22. Tausend, P. C., Goldstein, G. \& Meinzer, F. C. Water utilization, plant hydraulic properties and xylem vulnerability in three contrasting coffee (Coffea arabica) cultivars. Tree Physiol. 20, 159-168 (2000).

23. Gong, D., Kang, S., Yao, L. \& Zhang, L. Estimation of evapotranspiration and its components from an apple orchard in northwest China using sap flow and water balance methods. Hydrol. Process. 21, 931-938 (2007).

24. Dragoni, D., Lakso, A. N. \& Piccioni, R. M. Transpiration of apple trees in a humid climate using heat pulse sap flow gauges calibrated with whole-canopy gas exchange chambers. Agric. For. Meteorol. 130, 85-94 (2005).

25. Ferraz, T. M. et al. Relationships between sap-flow measurements, whole-canopy transpiration and reference evapotranspiration in field-grown papaya (Carica papaya L.). Theor. Exp. Plant Physiol. 27, 251-262 (2015).

26. Reis, Fd. O., Campostrini, E. \& de Sousa, E. F. Fluxo de seiva xilemática em mamoeiro 'Golden' cultivado por microaspersão sobre copa: Relações com as variáveis ambientais. Bragantia 68, 285-294 (2009).

27. Suvočarev, K., Blanco, O., Faci, J. M., Medina, E. T. \& Martínez-Cob, A. Transpiration of table grape (Vitis vinifera L.) trained on an overhead trellis system under netting. Irrig. Sci. 31, 1289-1302 (2013).

28. Cifre, J., Bota, J., Escalona, J. M., Medrano, H. \& Flexas, J. Physiological tools for irrigation scheduling in grapevine (Vitis vinifera L.): An open gate to improve water-use efficiency? Agric. Ecosyst. Environ. 106, 159-170 (2005).

29. Meinzer, F. C., James, S. A. \& Goldstein, G. Dynamics of transpiration, sap flow and use of stored water in tropical forest canopy trees. Tree Physiol. 24, 901-909 (2004).

30. Cárdenas, M. F., López-Ramírez, C., Mejía, J. D. \& Escobar, J. F. Design and implementation of a low-cost device for measuring sap flow in woody species1. DYNA 86, 213-220 (2019).

31. Miner, G. L., Ham, J. M. \& Kluitenberg, G. J. A heat-pulse method for measuring sap flow in corn and sunflower using 3D-printed sensor bodies and low-cost electronics. Agric. For. Meteorol. 246, 86-97 (2017).

32. Jarvis, P. G. The interpretation of the variations in leaf water potential and stomatal conductance found in canopies in the field. Philos. Trans. R. Soc. Lond. 273, 593-610 (1976).

33. Fraga Junior, L. S., Vellame, L. M., de Oliveira, A. S. \& da Silva Paz, V. P. Transpiration of young cocoa trees under soil water restriction. Sci. Agric. 78, e20190093 (2020).

34. Dierick, D. \& Hölscher, D. Species-specific tree water use characteristics in reforestation stands in the Philippines. Agric. For. Meteorol. 149, 1317-1326 (2009).

35. Alvim, P. T. Relações entre fatores climáticos e produção do cacaueiro. in Proceedings of the 10th international cocoa research conference 159-167 (1988).

36. Suárez, J. C. et al. Photosynthesis limitations in cacao leaves under different agroforestry systems in the Colombian Amazon. PLoS ONE 13, e0206149 (2018).

37. Franks, P. J. Higher rates of leaf gas exchange are associated with higher leaf hydrodynamic pressure gradients. Plant Cell Environ. 29, 584-592 (2006).

38. Alvim, P. T. Cacao. in Ecophysiology of Tropical Crops. (ed. Alvim, P. T. \& K. T.) 279-313 (Academic Press, 1977).

39. Wood, G. A. Enviromental. in Cocoa (ed. Wood GAR, L. R.) 38-78 (1985).

40. Harja, D. \& Vincént, G. Spatially explicit individual-based forest simulator - user guide and software (World Agroforestry Centre (ICRAF); Institut de Recherche pour le Développement (IRD), Bogor, Indonesia, 2008).

41. Quesada, F., Somarriba, E. \& Malek, M. ShadeMotion 3.0: Software para calcular la cantidad de horas de sombra que proyectan un conjunto de árboles sobre un terreno (2007).

42. Burgess, S. S. O. et al. An improved heat pulse method to measure low and reverse rates of sap flow in woody plants. Tree Physiol. 21, 589-598 (2001).

43. Marshall, D. C. Measurement of sap flow in conifers by heat transport. Plant Physiol. 33, 385-396 (1958).

44. Becker, P., \& Edwards, W. R. N. Corrected heat capacity of wood for sap flow calculations. Tree Physiology, 19(11), 767-768 (1999).

45. Allen, R. G., Pereira, L. S., Raes, D. \& Smith, M. Evapotranspiración del cultivo. Guías para la Determ. los requerimientos agua los Cultiv. Estud. FAO Riego y Dren. 56 (2006).

46. Pinheiro, J., Bates, D., DebRoy, S., Sarkar, D. \& Team, R. C. nlme: Linear and nonlinear mixed effects models. R Packag. version 3.1-1393, 111 (2019).

47. R Development Core Team. R: The R Project for Statistical Computing. In: Foundation for Statistical Computing, V., Austria. ISBN 3-900051-07-0 (Ed.). (2019).

48. Di Rienzo, J. A. et al. Infostat - Software estadístico. InfoStat versión 2019. Centro de Transferencia InfoStat, FCA (Universidad Nacional de Córdoba, Argentina, 2019).

49. Vezy, R. et al. Measuring and modelling energy partitioning in canopies of varying complexity using MAESPA model. Agric. For. Meteorol. 253-254, 203-217 (2018).

50. Zambrano, M. hydroGOF: Goodness-of-fit functions for comparison of simulated and observed hydrological time series. $R$ Packag. version 0.3-8 (2014).

51. López-López, R., Ojeda-Bustamante, W., López Andrade, A. P. \& Catalán-Valencia, E. A. Heat pulse method and sap flow for measuring transpiration in cacao. Rev. Chapingo Ser. Zo. Áridas XII, 85-96 (2013).

52. Abdulai, I. et al. Cocoa agroforestry is less resilient to sub-optimal and extreme climate than cocoa in full sun. Glob. Change Biol. 24, 273-286 (2018).

53. Wood, G. A. Environment. in Cocoa (eds. Wood, G. A. R \& Lass, R. A.) 38-78 (1985).

54. Arcila, J. Crecimiento y desarrollo de la planta de Café. in Sistemas de producción de café en Colombia (ed. Arcila, J., Farfán, F., Moreno, A., L. F. \& Salazar, E. H.) 21-60 (2007).

55. Alvim, P. T. Cacao. in Ecophysiology of Tropical Crops. (eds. Alvim, P. T. \& Kozlowski, T. T.) 279-313 (1977).

56. IDEAM. Atlas Climatológico de Colombia Interactivo. http://atlas.ideam.gov.co/visorAtlasClimatologico.html (Bogotá, D.C., 2020).

57. Suárez, J. C., Ngo Bieng, M. A., Melgarejo, L. M., Di Rienzo, J. A. \& Casanoves, F. First typology of cacao (Theobroma cacao L.) systems in Colombian Amazonia, based on tree species richness, canopy structure and light availability. PLoS ONE 13, e0191003 (2018).

58. Niether, W., Armengot, L., Andres, C., Schneider, M. \& Gerold, G. Shade trees and tree pruning alter throughfall and microclimate in cocoa (Theobroma cacao L.) production systems. Ann. For. Sci. 75, 1-16 (2018).

59. Burgess, S., Pate, J. S., Adams, M. A. \& Dawson, T. E. Seasonal water acquisition and redistribution in the australian woody phreatophyte, Banksia prionotes. Ann. Bot. 85, 215-224 (2000).

60. Forster, M. A. How significant is nocturnal sap flow?. Tree Physiol. 34, 757-765 (2014). 
61. Rico, A. Caracterizacion de las Estructuras Agroforestales y su Relacíon con el Balance Hídrico en Arreglos con Theobroma Cacao L. En la Amazonia Occidental Colombiana. Universidad de la Amazonia. Programa de Ingenieria Agroecologica. 84 p. 2014.

62. Prieto, I., Armas, C. \& Pugnaire, F. I. Water release through plant roots: New insights into its consequences at the plant and ecosystem level. New Phytol. 193, 830-841 (2012).

63. Dawson, T. E. et al. Nighttime transpiration in woody plants from contrasting ecosystems. Tree Physiol. 27, 561-575 (2007).

64. Rosado, B. H. P., Oliveira, R. S., Joly, C. A., Aidar, M. P. M. \& Burgess, S. S. O. Diversity in nighttime transpiration behavior of woody species of the Atlantic Rain Forest Brazil. Agric. For. Meteorol. 158-159, 13-20 (2012).

65. Zeppel, M. J. B., Lewis, J. D., Phillips, N. G. \& Tissue, D. T. Consequences of nocturnal water loss: A synthesis of regulating factors and implications for capacitance, embolism and use in models. Tree Physiol. 34, 1047-1055 (2014).

66. Domec, J. C. et al. Interactive effects of nocturnal transpiration and climate change on the root hydraulic redistribution and carbon and water budgets of southern United States pine plantations. Tree Physiol. 32, 707-723 (2012).

\title{
Acknowledgements
}

This project was carried out with the financial collaboration of COLCIENCIAS using BID funds under the framework "Characterization and classification of traditional Theobroma cacao plantations as a strategy for the design and implementation of agroforestry arrangements in the Bajo Caguán (Cartagena del Chaira)", carried out by Amazonia University through a special contract of cooperation 590 from 2012. To the Amazonia University funds for Doctoral Training under the seal "Pro-development of Amazonia University" Law No. 1301 of 2009. The authors thank the Mesoamerican Platform for Scientific Cooperation in Agroforestry Systems with Perennial Crops for their academic and financial support for the development of this manuscript. CA had a "Ramón y Cajal" contract from the Spanish Government and CSIC (RYC-2012-12277). We are grateful to Rocio Labrador, MSc at Princeton University for her English style editions.

\section{Author contributions}

J.C.S., F.C., L.M.M., M.A.N.B and C.A. designed the experiments. J.C.S., develop the field experiments and collect the information. J.C.S., F.C., J.D.R., analyzed the data and generated the models. J.C.S., M.A.N.B. and C.A. contributed to the writing of the manuscript and all authors revised the different versions.

\section{Competing interests}

The authors declare no competing interests.

\section{Additional information}

Correspondence and requests for materials should be addressed to J.C.S.

Reprints and permissions information is available at www.nature.com/reprints.

Publisher's note Springer Nature remains neutral with regard to jurisdictional claims in published maps and institutional affiliations.

\begin{abstract}
(c) (i) Open Access This article is licensed under a Creative Commons Attribution 4.0 International License, which permits use, sharing, adaptation, distribution and reproduction in any medium or format, as long as you give appropriate credit to the original author(s) and the source, provide a link to the Creative Commons licence, and indicate if changes were made. The images or other third party material in this article are included in the article's Creative Commons licence, unless indicated otherwise in a credit line to the material. If material is not included in the article's Creative Commons licence and your intended use is not permitted by statutory regulation or exceeds the permitted use, you will need to obtain permission directly from the copyright holder. To view a copy of this licence, visit http://creativecommons.org/licenses/by/4.0/.
\end{abstract}

(C) The Author(s) 2021 